2016-11-14

\title{
Evaluating undergraduate research conferences as vehicles for novice researcher development
}

Kneale, Pauline

http://hdl.handle.net/10026.1/9576

\author{
10.1108/IJRD-10-2015-0026 \\ International Journal for Researcher Development \\ Emerald
}

All content in PEARL is protected by copyright law. Author manuscripts are made available in accordance with publisher policies. Please cite only the published version using the details provided on the item record or document. In the absence of an open licence (e.g. Creative Commons), permissions for further reuse of content should be sought from the publisher or author. 
Evaluating undergraduate research conferences as vehicles for novice researchers and transferable skills development

*Kneale, Pauline. E.

Pro Vice-Chancellor Teaching and Learning

Plymouth University,

3 Endsleigh Place,

Plymouth PL4 8AA UK

Tel + 00441752584881

pauline.kneale@plymouth.ac.uk

Edwards-Jones, Andrew.

Plymouth University,

3 Endsleigh Place,

Plymouth PL4 8AA UK

Tel + 00441752584879

aedwards-jones@plymouth.ac.uk

Walkington, Helen.

Department of Social Sciences

Oxford Brookes University

Oxford OX3 0BP UK

Tel + 00441865483185

hwalkington@brookes.ac.uk

Hill, Jennifer.

Department of Geography and Environmental Management

University of the West of England

Coldharbour Lane

Bristol BS16 1QY UK

Tel + 00441173283042

Jennifer.Hill@uwe.ac.uk

*Corresponding author 


\begin{abstract}
Purpose - This paper focuses on the undergraduate research conference as its sphere of study and investigates the significance of participation and socialisation in such activities on student attitudes and professional development. Using situated learning to theoretically position the undergraduate research conference as an authentic learning context, connection is also made to the concept of graduate attributes.
\end{abstract}

Design/methodology/approach - The Vitae (2014) Researcher Development Framework (RDF) is used to provide a template for charting the experiences and development of undergraduate students as researchers. This can be applied to short-term activities and programmes as well as to long-term career plans. The insights from 90 undergraduate students participating at three national undergraduate research conferences were obtained through interviews, and thematically analysed to map the students' skills development against the RDF criteria.

Findings - Three main aspects of undergraduate research conference participation were considered particularly important by the students: the value of paper presentations, the value of poster presentations, and the value of the overall conference experience. Within these themes, participants identified a wide range of skills and attributes they felt they had developed as a result of either preparing for or participating in the conferences. The majority of these skills and attributes were able to be mapped against the different domains of the RDF, using a public engagement lens for comparing actual with expected developmental areas.

Research limitations/implications - This research helps undergraduate research conference organisers construct programme content and form in such a way that student skills development can be maximised prior to, and during, the course of an event. Learning Developers can also use these findings to help understand the support needs of students preparing to deliver papers at such conferences. So far, little empirical research has examined students' skills development within the undergraduate research conference arena.

Originality/value - The outcomes of this study show the diversity of skills students developed, and the value of the conference format to offer networking practice and to enhance the communication skills which employers value.

Keywords: undergraduate research conference; communication; Researcher Development Framework; employability skills; student development.

Article Type: Research Paper 


\section{Introduction}

The skills gap in the UK between education and work is well described (Archer and Davison, 2008; UKCES $2014 \mathrm{a}$ and b). As an integral part of the research cycle, dissemination through conference participation potentially develops specific research skills that are highly sought after by employers (Hill and Walkington, 2012; Walkington, 2014). The Vitae (2014) Researcher Development Framework (RDF) offers a detailed mechanism to map core skills that are developed or acquired through, or used in, the broader contexts of being a researcher. While primarily used with postgraduate researchers, the RDF can provide a template for evaluating and mapping undergraduates' skills. Bray and Boon's (2011) evaluation of the framework concluded that participants found this approach useful in facilitating career development.

Although involvement in research is recognised as offering transformational experiences for undergraduates (Guterman, 2007; Hunter, Laursen and Seymour, 2007; Seymour et al., 2004), the dissemination phase is generally underplayed (Spronken-Smith et al., 2013). Specific gains from research engagement include advancing cognitive and intellectual growth, fostering professional advancement, promoting personal growth, and maximising high impact learning experiences (Osborne and Karukstis, 2009).

Chickering and Gamson (1999) consider the 'integration of education and experience' as an attribute of quality (Ewell \& Jones, 1996). Experiential research opportunities for students might involve vacation research programmes, staff-led research apprenticeships, capstone research projects, undergraduate conference presentations and journal publications. The National Science Foundation's best practice guide for educational programmes notes the importance of dissemination as part of the provision of 'undergraduate research opportunities that are visible, provide support, and offer a means of showcasing the product' (Kinkead, 2003 , p10). These criteria can be satisfied by participation in academic conferences. The experience of presenting their own research affords students an opportunity to learn about the relationship between deep understanding of their subject and the process of communicating their findings and recommendations (Spronken Smith et al., 2013). Research dissemination completes the research cycle, going beyond submission of a final year project for assessment, drawing students into disciplinary research practices (Healey and Jenkins, 2009; Mabrouk, 2009). 
In summary, the literature evidences a range of benefits from active participation in academic conferences: establishing good practice through observation of experts, learning how to communicate with a diverse audience, gaining greater independence, tolerating uncertainty, problem-solving, increasing self-confidence and enhancing career prospects (Garafa and Brians, 2011; Hill and Walkington, 2016; Lopatto, 2009; Seymour et al., 2004; Walkington, $2008 ; 2015)$.

Opportunities are, however, limited for student participation in research dissemination beyond institutional campuses. Many HEIs hold discipline-led undergraduate research conferences (Healey and Jenkins, 2009; Spronken-Smith et al., 2013), but Lopatto (2009), surveying US undergraduate research programmes, found that professional presentations comprised just $8 \%$ of all undergraduate presentation types (the other $92 \%$ being made up of campus-based poster and verbal paper presentations, and written papers). However, there is increasing interest in the US for regional and national events that provide students with broader academic experiences e.g. the annual National Conference of Undergraduate Research (NCUR), the Northwest Undergraduate Conference for Literature (NUCL), and the Southern California Conferences for Undergraduate Research (SCCUR) (Swift et al., 2012). The NCUR and The Student Conference on Conservation Science (SCCS) have international reach, the latter being hosted in several countries (Jenkins and Healey, 2007).

Elsewhere, the British Conference of Undergraduate Research (BCUR), the Australian Conference of Undergraduate Research (ACUR), and the Student Research Conference in the Netherlands have growing numbers, increasing the range of learning experiences for students and situating students in a 'marketplace of ideas' (Hersh, Hiro, and Asarnow, 2011). Spronken-Smith et al.'s (2013) framework for dissemination of undergraduate research and inquiry situates the undergraduate conference at the summit of levels of student autonomy and exposure (a combined measure of "public-ness", extent of activity beyond the taught curriculum, and potential sphere of influence).

While a number of studies have evaluated student feedback following a conference programme (Helm and Bailey, 2013; Hersh, Hiro, and Asarnow, 2011; Hill and Walkington, 2016), this paper focuses on investigating the significance of participation and socialisation at three BCUR conferences, and the impact on student skills, abilities and professional growth. The results are mapped against the four domains of the RDF (Vitae, 2014) (Figure 1) to see 
how these events contribute to the development of skills that employers value. The outcomes enable us to reflect on the components of a conference that have particular value to students. The mapping of interview data onto the RDF using different elements of conference activity represents a novel approach to the analysis of learning gains from an undergraduate research conference.

\section{The Researcher Development Framework}

The RDF is an operational framework that underlies the Researcher Development Statement (RDS), a strategic statement setting out the knowledge, behaviours, skills and attributes of skilled researchers. Endorsed by Research Councils UK and Universities UK, the two instruments reinforce the implementation of the Concordat to Support the Career Development of Researchers, and the QAA Code of Practice for research degree programmes (Vitae, 2014). The RDF was intended by its developers to represent a major new approach to researcher development, providing a tool for planning, promoting and supporting the personal, professional and career development of researchers (Vitae, 2014) The RDF is primarily aimed at those who are 'doing a doctorate, are a member of research staff, pursuing an academic career or thinking about applying the skills developed during a $\mathrm{PhD}$ in another career' (Vitae, 2014). However, the authors suggest that, because the framework is multilayered, setting out both core and advanced skills and attributes, it might reasonably be used to map skills and attributes developed and evidenced during undergraduate research experiences.

\section{Conceptual framework}

This study draws on situated learning theory (Lave and Wenger, 1991), based on the premise that the academic conference environment provides undergraduates with an authentic learning context in which the novice student learns and improves a range of skills, scaffolded through social interaction and collaboration with their peers and with more experienced members of the academic community (tutors). The learning journey experienced by each student, from pre-conference preparation, through presentation and networking, to postconference debriefing, reflection and potential collaboration, is expected to move the student toward expert standing, a journey that can be effectively captured by the RDF. As the undergraduates participating in the BCUR conferences were particularly motivated, with many aspiring to progress their careers in research and academia, this journey will likely be 
further enhanced by a greater understanding of, and sense of belonging to, the academic community of practice as a result of the overall conference experience (Wenger, 1998).

Conferences as situated learning environments have been explored previously. Anderson and Passera (2015), for example, embedded a mini-conference in their undergraduate business course where student 'experts', who completed reviews of specified journal articles, copresented on contemporary developments in their allocated research area. Meanwhile, 'novices', who were briefed by the 'experts', co-presented the application of their learning to practical business scenarios. The aim of the conference is to provide a non-threatening environment in which students can rehearse their ideas and share insights, developing analytical skills within a community of practice. Meanwhile, Xiangdong (2015) found that mock conferences for undergraduate student interpreters develop skills concerning professionalism, psychological competence and strategic competence thereby preparing students for their professional careers.

The importance of undergraduate students developing research-related and other skills in order to prepare them for work is linked to the concept of graduate attributes. Many graduate attribute models explicitly include research and inquiry skills (Barrie 2004; Hounsell, 2011), and the graduate attributes literature informed the aims of this paper. Firstly, the literature highlighted the importance of offering students co-curricular authentic learning experiences to help develop their graduate attributes (Hill and Walkington, 2016). Secondly, it demonstrated the need for students to reflect on the progressive acquisition of skills over their learning journeys (Fraser and Thomas, 2013; Su, 2014). In response, we recognised that BCUR conferences offer a quasi-professional space for students to practice and develop their research skills, whilst the RDF provides a framework to guide conversations between academic staff and students, providing transparency for the development of core skills through engagement in research.

\section{Methodology}

Ninety semi-structured 15-30 minute interviews were conducted with students during the 2012, 2013 and 2014 BCUR conferences. The conference formats included both paper and poster sessions, with the titles of each presentation detailed within the programmes. Students were approached following their presentations and invited to take part in a short face-to-face interview. The number of interviews carried out was limited by the capacity of the research 
team rather than a lack of volunteer participants. The sample across the three years represented $14 \%$ of the total number of students who presented their work at these conferences. Sampling was determined by the conference schedules rather than through selections based on gender, ethnicity or institution. The conference had a good spread of disciplines across the arts and humanities, health and social care, social sciences, and science, technology, engineering and mathematics (STEM). The majority of respondents were finalyear students presenting their capstone research, summer research project or independent research. A minority were in their second year of studies and a few had undertaken independent research specifically for the conference. There were roughly equal proportions of students who delivered poster compared to verbal paper presentations and the participant sample was largely balanced in terms of gender. Data were not systematically collected for demographic characteristics such as race/ethnicity or socio-economic class.

The research project passed through the ethical review processes of Plymouth University. Interviewees were informed about the aims of the research and their ability to withdraw from the research process at any stage. They were also assured that their comments would be cited anonymously. The respondents thereby offered informed consent to be questioned and to have their responses audio-recorded. The authors received permission from the organising committees to undertake interviews during the conferences.

Semi-structured interviews were chosen as the data collection instrument because they are an efficient method for enabling deep exploration of respondents' experiences, feelings and opinions on a subject (Miles et al., 2015). The interviews allowed students to reflect personally on their conference experience and they also permitted some flexibility in followup questions. They were therefore chosen for their reflexivity and immediacy (Galetta, 2013). The interviews explored student perspectives of their conference experience, including reflections on the preparation and delivery of workshop sessions, networking events, plenary sessions and social activities. The questions aimed to elicit specific skills associated with the different elements of the conference. Interviews were digitally recorded and transcribed in full.

Data analysis of the 90 interviews adopted a constant comparative approach (as summarised by Taylor and Bogdan, 1984), utilising NVivo qualitative analysis software to assist in the thematic exploration of data (Bazeley and Jackson, 2013), categorical derivation of key points of interest, and building relationships between the main categories and sub-categories. 
Themes and categories were derived from an open coding process (Strauss and Corbin, 1998) (see Table 1). To enhance reliability of categorisation, the process of reading the transcripts and organising statements under codes was repeated several times and cross-checked by the authors. After coding, the skills and attributes identified by students as having been developed during the conference were mapped onto the RDF (Table 2).

\section{Results}

Students were very positive about their experiences of participating in the BCUR conferences. Participants identified a wide range of skills and attributes they felt they had developed as a result of either preparing for or participating in the conferences. These perceived gains provide a means to evaluate each conference element. Data analysis allowed categorisation of the relationship between the coded benefits and the elements of the conference where they were developed and evidenced (Table 1).

Three main areas of learning were identified: the value of paper presentations; the value of poster presentations; and the value of the overall conference experience. Table 1 shows how these themes were built up from sub-themes and clustered; the sub-themes being presented in order of the number of references made during the interviews (therefore totals are sometimes

higher than the number of interviewees). Each of these themes is now explored in more detail using students' own words. 
Table 1: Themes reflecting the perceived value of conference features

\begin{tabular}{|c|c|}
\hline Theme & $\begin{array}{l}\text { Number of references in } \\
\text { interviews }\end{array}$ \\
\hline 1. Value of paper presentations to all participants & 205 \\
\hline i. Developing skills (overall) & 58 \\
\hline - confidence and technique in public speaking & 33 \\
\hline - reduction of information & 14 \\
\hline - industry training & 6 \\
\hline - technical competence & 3 \\
\hline - time management & 2 \\
\hline ii. Learning to direct work at interdisciplinary audience & 36 \\
\hline \multicolumn{2}{|l|}{ iii. Gaining new knowledge in other disciplines and insights } \\
\hline about research & 32 \\
\hline iv. Receiving and giving useful or critical feedback & 26 \\
\hline v. Observing good practice & 18 \\
\hline vi. Shared experience & 13 \\
\hline \multicolumn{2}{|l|}{ vii. Other: } \\
\hline - progressed the research process & 9 \\
\hline - professional validity & 5 \\
\hline - collating presentations into themes & 3 \\
\hline - enhanced own standards and style & 3 \\
\hline - paper format more suited to subject & 2 \\
\hline 2. Value of poster presentations to all participants & 132 \\
\hline i. Developing skills - overall & 69 \\
\hline - concise writing for generic audience & 33 \\
\hline - confidence to communicate research & 17 \\
\hline - enhancing employability & 14 \\
\hline - the potential usefulness of inter-disciplinary collaboration & 5 \\
\hline - working the crowd & 2 \\
\hline ii. Critical feedback to improve own skills & 20 \\
\hline \multicolumn{2}{|l|}{ iii. Other: } \\
\hline - gaining new knowledge in other disciplines & 14 \\
\hline - progressed the research process & 12 \\
\hline - more informal introduction to dissemination & 9 \\
\hline - gaining ideas and inspiration & 8 \\
\hline 3. Value of the overall conference experience & 86 \\
\hline
\end{tabular}



i. Active networking events and social interactions
ii. Being part of a community of practice
iii. Being in a supportive and encouraging environment

The unit of measurement for these data is the number of references made to themes during the interviews, therefore totals can be higher than the number of interviewees.

\section{Value of paper presentations to all conference participants}

Seven main sub-themes comprise this theme, which concerns the oral delivery of paper presentations by the interviewees, or the attendance by them at workshop sessions to see their peers' presentations. Students recognised that there are skills to be gained from both aspects of a workshop.

\section{i. The development of skills}

By far the most frequently reported skill was increased confidence associated with public speaking:

'I think just presentation skills ... to actually be there as me and have the confidence to present my own work, $[\mathrm{I}]$ felt very vulnerable but it was actually quite a positive experience. But once I was up there I was absolutely fine, it was just in the run up to it that I was a bit of a wreck.'

'The key skills I wanted to really develop were my public speaking and presentation skills; you may have noticed yesterday I was speaking very slowly in quite a relaxed cadence and that was something that I wanted to really develop ... so that was the key thing that I developed there and the practicing for the paper, getting the timings down, all those were something that I wanted to work on.'

Students learnt how to reduce large amounts of information and present the main findings in a meaningful and engaging way:

'Definitely laying it out, and being concise as well, trying to get an eight thousand word dissertation into like ten slides or so is difficult, but that's the key skill I probably got from it.'

Other enhanced skills reported by participants included the ability to mirror professional/industry job requirements, technical competencies and time management. 


\section{ii. Learning to communicate with interdisciplinary audiences}

Students recognised the multi-disciplinary nature of the BCUR audiences and adapted their talks accordingly. Some individuals felt a more personal experiential approach to presenting was helpful, while others added definitions of technical terms and concepts to their slides:

'Actually it's quite challenging because obviously the dissertation's quite a specific piece of research but you come here to a general conference and it's quite hard to kind of communicate what the problem is, what the solution to the problem is, but also how you get there in a way that everyone can appreciate and understand. So it was really difficult to tick all three of those boxes as well as make it interesting and engaging for the average attendee.'

\section{iii. Gaining new knowledge in other disciplines and new awareness about research}

Several of the students were surprised by the broad diversity of subjects covered by their peers' presentations and found genuine interest in this face-to-face learning:

'lots of people are interested in a lot of different areas of research and at these conferences, where there's so many different subjects, you can communicate with somebody on an intellectual level about a subject which you have no idea about. So I went to some seminars on economics yesterday and I have no idea about it but found it equally interesting and understood it.'

Participants mentioned both enjoying hearing about other people's research, and gaining new awareness of different approaches, methods and applications of research used within disciplines other than their own.

\section{iv. Receiving and giving useful or critical feedback}

Students valued the critical feedback following their own presentations and providing constructive comment to others. Often, this meant conquering fears and anxieties by deliberately placing themselves outside their comfort zones:

'I want the most feedback as possible, because I've had to make my own methodology, everything's my own research, with a little bit of help, but what I'm doing nobody's done yet. So I'm trying to get lots of people to help me revise and critique it and so I can perfect it, because hopefully ... people are going to use it within the field and so it's great to finally have it as a public sort of thing, my debut.'

v. Observing good practice 
'I've tried to go to humanities talks, which have gone a little bit over my head, but I've learnt a different way to communicate things and that's been probably the most important thing that I've learnt, is how people get their work across to people like me. I'm not a humanities student but I kind of got what was going on in the end so, and that's the most important thing I've learnt for sure in terms of skills.'

While attending other people's presentations, some students noted differences in presentation techniques, use of intonation, body language, facial expressions and the benefits of an interactive approach. Students itemised many examples of 'what not to do' and better habits, most notably the importance of avoiding too much technical jargon.

\section{vi. A shared experience}

Students recognised the developmental nature of BCUR and appreciated that everyone was experiencing similar anxieties, doubts and also excitement. Because most participants in these conferences do actually present at some stage, there was a general sense of mutual support:

'It's a kind experience; it's like you've got at least three other people on your panel and you know they've all done the same thing and gone through a lot of hard work, so they all know what you're going through ... everyone's in the same boat, so no-one's going to ridicule you here but they might if you were in a more professional kind of body.'

\section{vii. Other}

Other ways in which individuals valued paper presentations included the influence feedback was going to have on the progression of their current research i.e. when writing up a thesis; the sense of professional validity that presenting at a conference gave them; and the additional creative freedom when University assessment criteria are removed.

\section{Value of poster presentations to all conference participants}

The two dominant sub-themes emerging from students presenting posters were the development of skills and gaining critical feedback with a view to self-improvement.

\section{i. The development of skills}

Students found it a challenging and productive exercise to refocus their research findings in concise poster format: 
'Being concise, yeah, I consistently have a problem with being concise and I think making a poster really can help you on that side of things. It's important to know how to be concise with what you're trying to say, so it's been good practice for that definitely, yeah.'

More specifically, students mentioned the need to think about selecting the most important elements of their research, ensuring the finished product was understandable and engaging for the 'layman'. This re-thinking was evident when presenting the poster, where authors discussed their research and responded to questions:

'I understand something when people come and ask me lots of questions about it and then I have to re-explain it. I find it really clarifies things in my own head - it's one of the ways I learn best'

Students talked about these sessions helping to build up their confidence to communicate their research findings, enhancing their employability skills, and revealing previously unrecognised opportunities for collaboration between disciplines as a result of discussions with fellow participants.

\section{ii. The gaining of critical feedback}

A number of students were actively seeking critical feedback as a personal objective of attendance at the conferences, using the experience to get suggestions for improving their research work and for self-improvement:

'I wanted to get real feedback, like critical feedback. I mean it's something I want to do with my life so I would like to know how to become better and how to be a professional.'

The multidisciplinary nature of the conferences did not prohibit presenters from asking each other challenging questions, negating frequently expressed concerns that their own research might not be of wider interest. Some students found unexpected gains with respect to their approach to research, for example being introduced to new methodologies and different applications of known methods:

'... being asked different ways about my methodology, for example, has influenced what my methodology's going to be for my next research project.'

Receiving critical feedback prepares researchers for the peer review processes associated with publication, technical academic conference submissions and report writing. Overall, students respected and welcomed this developmental aspect. 
A few students indicated the experience was influencing their dissertation work. Their conversations had provided further practical ideas for additional experiments, highlighted the broader significance of results, and indicated ways to discuss results in final reports.

\section{Value of the overall conference experience}

Of the three sub-themes that were thought to best capture the students' overall conference experience, by far the most evident was the value placed on networking and interacting with peers and tutors.

\section{i. Active networking events and social interactions}

The student interviewees felt that networking generated a dynamic feel to the conferences, provided opportunities to be signposted to useful resources, raised new areas of potential research interest, developed interpersonal skills, and piqued interest by introducing individuals from different cultural backgrounds and nationalities to each other. Students were generally positive about networking, recognising that this aspect of the conferences set them apart from institutional discipline-based events.

Several students clearly wanted to target their networking effort and use the limited time available to converse with potential collaborators or individuals involved in similar academic disciplines:

'I really enjoy talking to people ... so yesterday I met a guy who is from a sociological background, which is what I am going in to, so it was really nice to be able to talk to him ... in a few years' time we could be, you know, potentially in the same sphere, so it's good to be able to know how to effectively network and who to target, rather than just go and talk to everybody. Because there are so many people here, it is important to know who the people are that you should really focus on.'

Regarding the opening sessions designed to explain how conferences work, the different styles of poster and paper presentations, the importance and value of asking questions and of practicing networking skills, most students reported that the sessions helped them to realise the benefits of networking. More specifically, structured activities enabled students to share different learning experiences from people at different institutions, make contacts and develop skills of condensing research information into key headlines suitable for short rapidfire exchanges: 
'The focused discussion of networking and what it is to network and how to network ... my confidence in approaching new groups of people and breaking into new people still needs work and so every step in that direction is a good step in terms of learning specific skills.'

\section{ii. Being part of a community of practice}

Many students commented on the relaxed relationships between academic staff and students, and the lack of hierarchical relationships in discussions. Even when attendees were more familiar with the conference process, there were unforeseen outcomes:

'I've been to conferences as a presenter and as an attendee and so you see that side of things, but to hear the very different ways that these guys are thinking, sort of with the publishing, how to get your work out there and disseminate your work but from the point of view of the professional academic as opposed to the student was quite an interesting thing I wouldn't have expected to have.'

Students gained insights into professional academic life and saw the conferences as a 'step up' to the next level of professionalism. For those with PhD places, attendance and presenting offered valuable training for the future.

These conferences helped build student confidence, which can sometimes be inhibited in mainstream academic discipline conferences:

'It's just that I feel more like an equal here, which makes me feel more confident rather than if I go to a normal conference and then they say what do you do and I say well I'm an undergraduate student and you know, I just feel less confident then. So that's been really good to have that.'

There was also a sense that attending BCUR was more prestigious than participating in HEI events, and therefore more likely to impress employers in academia and beyond.

\section{iii. Being in a supportive and encouraging environment}

Some students voiced their appreciation of BCUR providing a supportive environment that enabled their confidence to grow and allowed them to 'get a feel for academia' before they ventured into further research and participated in professional conferences. 


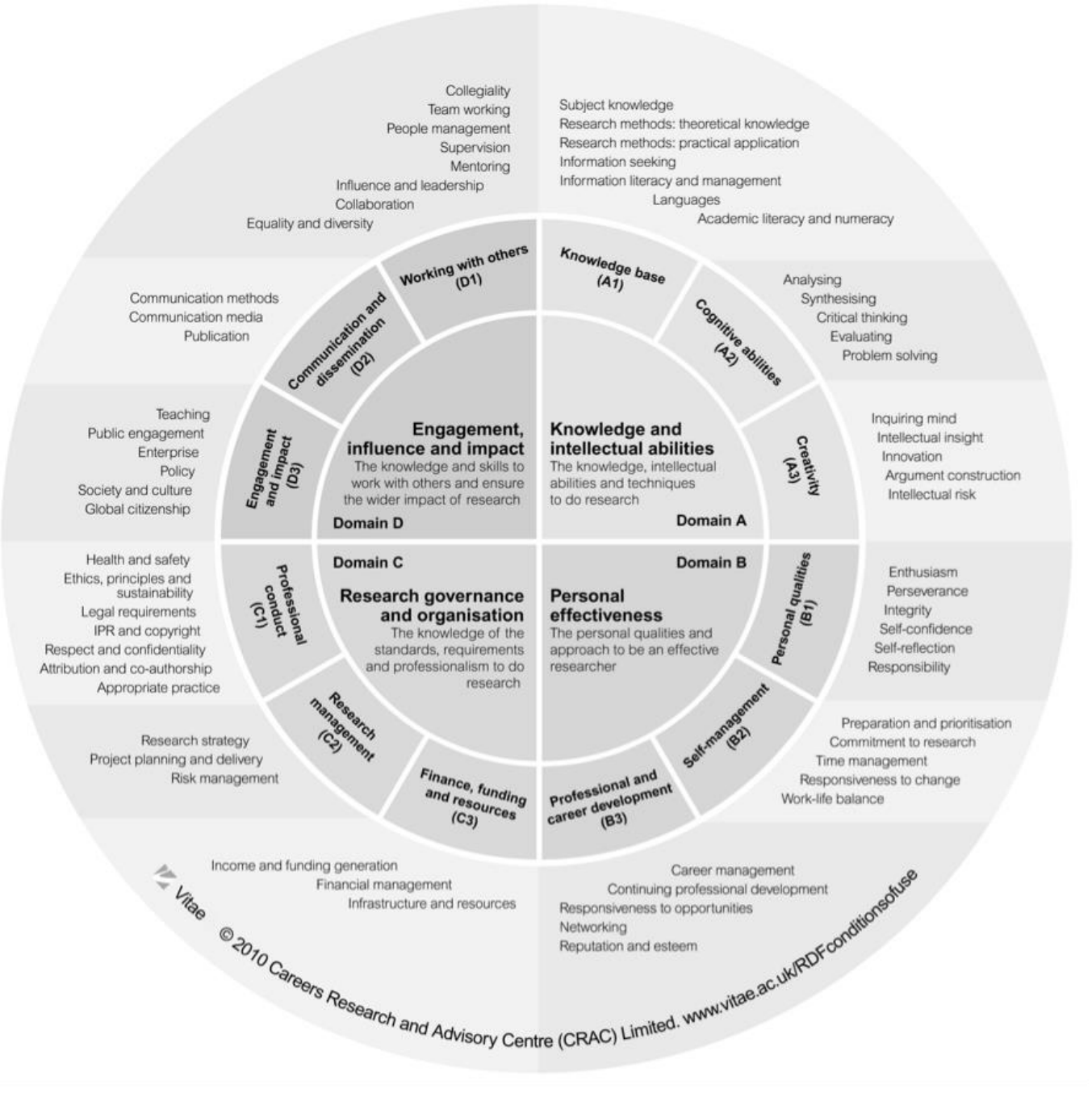

Reproduced with kind permission by Vitae

Figure 1: Vitae Researcher Development Framework domains and sub domains

Table 2: Mapping of BCUR presenter interview data against the public engagement lens on the Vitae (2014) Researcher Development Framework

\begin{tabular}{|l|l|l|l|}
\hline $\begin{array}{l}\text { Domain/Sub } \\
\text { Domain }\end{array}$ & Lens Descriptor & Core Skill & $\begin{array}{l}\text { Evidenced from } \\
\text { BCUR Data } \\
(\checkmark \text { X) and } \\
\text { strength of skill }\end{array}$ \\
\hline $\begin{array}{l}\text { Domain A: } \\
\text { Knowledge and } \\
\text { intellectual } \\
\text { abilities }\end{array}$ & & & \\
\hline
\end{tabular}




\begin{tabular}{|c|c|c|c|}
\hline $\begin{array}{l}\text { A1: Knowledge } \\
\text { base }\end{array}$ & $\begin{array}{l}\text { Engaging with the public can be } \\
\text { used to elicit insights, knowledge } \\
\text { and expertise from the public to } \\
\text { inform research and better } \\
\text { understand the relevance of research } \\
\text { to society }\end{array}$ & $\begin{array}{l}\text { - Can provide an overview of } \\
\text { their area of expertise; has a } \\
\text { secure knowledge and } \\
\text { understanding of the topic } \\
\text { they are engaging about } \\
\text { - Is willing to incorporate new } \\
\text { views into their own } \\
\text { understanding }\end{array}$ & $\begin{array}{l}\checkmark_{\text {High }} \\
\checkmark_{\text {High }}\end{array}$ \\
\hline $\begin{array}{l}\text { A2: Cognitive } \\
\text { abilities }\end{array}$ & $\begin{array}{l}\text { Collaborative working with the } \\
\text { public can bring new insights to } \\
\text { solve problems and approach } \\
\text { research from a new perspective }\end{array}$ & $\begin{array}{l}\text { Uses feedback mechanisms } \\
\text { that are accessible to the } \\
\text { public they are working with; } \\
\text { gathers feedback on } \\
\text { activities; is open to } \\
\text { constructive feedback; is } \\
\text { prepared to be disagreed with }\end{array}$ & $\checkmark$ High-Med \\
\hline A3: Creativity & $\begin{array}{l}\text { Understanding and being able to } \\
\text { respond to the publics' views of } \\
\text { research requires an inquiring mind } \\
\text { and being open to new sources of } \\
\text { ideas }\end{array}$ & $\begin{array}{l}\text { - Is willing to provide } \\
\text { supporting information; can } \\
\text { answer related questions; can } \\
\text { elicit and answer audience } \\
\text { questions } \\
\text { - Is open to new ways of } \\
\text { working; is willing to } \\
\text { consider differing views }\end{array}$ & $\begin{array}{l}\checkmark \text { High-Med } \\
\checkmark \quad \text { Med }\end{array}$ \\
\hline \multicolumn{4}{|l|}{$\begin{array}{l}\text { Domain B: } \\
\text { Personal } \\
\text { effectiveness }\end{array}$} \\
\hline $\begin{array}{l}\text { B1: Personal } \\
\text { qualities }\end{array}$ & $\begin{array}{l}\text { Engaged researchers report that the } \\
\text { public's interest in their research } \\
\text { reignites their enthusiasm and } \\
\text { passion for their research area }\end{array}$ & $\begin{array}{l}\text { Reflects on their practice and } \\
\text { tries to learn from their } \\
\text { experience; shows evidence } \\
\text { of learning; is able to } \\
\text { recognise when professional } \\
\text { help is needed }\end{array}$ & $\sqrt{\text { Low }}$ \\
\hline $\begin{array}{l}\text { B2: Self- } \\
\text { management }\end{array}$ & $\begin{array}{l}\text { Public engagement can provide an } \\
\text { opportunity to apply and develop } \\
\text { skills in running projects, which can } \\
\text { develop skills such as time } \\
\text { management, preparation and } \\
\text { prioritisation }\end{array}$ & $\begin{array}{l}\text { None specified (advanced } \\
\text { skills only) }\end{array}$ & $\checkmark$ Low \\
\hline $\begin{array}{l}\text { B3: Professional } \\
\text { and career } \\
\text { development }\end{array}$ & $\begin{array}{l}\text { Public engagement can raise } \\
\text { researchers' profiles, enhance their } \\
\text { reputation, build networks and } \\
\text { relationships, and develop skills that } \\
\text { enhance their employability both } \\
\text { within and outside academia }\end{array}$ & None specified & $\boldsymbol{V}_{\text {High }}$ \\
\hline $\begin{array}{l}\text { Domain C: } \\
\text { Research } \\
\text { governance and } \\
\text { organisation }\end{array}$ & & & \\
\hline
\end{tabular}




\begin{tabular}{|c|c|c|c|}
\hline $\begin{array}{l}\mathrm{C} 1 \text { : Professional } \\
\text { conduct }\end{array}$ & $\begin{array}{l}\text { Engagement projects develop skills } \\
\text { of empathy, listening, } \\
\text { communication and respect for } \\
\text { others. }\end{array}$ & $\begin{array}{l}\text { - Operates in a professional } \\
\text { manner at all times } \\
\text { - Identifies social, political and } \\
\text { ethical issues of relevance to } \\
\text { particular audiences }\end{array}$ & $\begin{array}{l}\text { Med } \\
\mathrm{X}\end{array}$ \\
\hline $\begin{array}{l}\text { C2: Research } \\
\text { management }\end{array}$ & $\begin{array}{l}\text { Public engagement activities often } \\
\text { require an ability to plan and deliver } \\
\text { projects, and provide a relatively } \\
\text { easy way to use and develop these } \\
\text { skills. Public engagement can } \\
\text { inform research so it contributes to } \\
\text { the wider aims of all stakeholders }\end{array}$ & None specified & $X$ \\
\hline $\begin{array}{l}\text { C3: Finance, } \\
\text { funding and } \\
\text { resources }\end{array}$ & $\begin{array}{l}\text { Public engagement can enable } \\
\text { researchers to maximise and } \\
\text { communicate impact and potential } \\
\text { impact more effectively through } \\
\text { funding proposals, RCUK's } \\
\text { Pathways to Impact, Research } \\
\text { Excellence Framework (REF) } \\
\text { impact templates and case studies }\end{array}$ & None specified & $X$ \\
\hline \multicolumn{4}{|l|}{$\begin{array}{l}\text { Domain D: } \\
\text { Engagement, } \\
\text { influence and } \\
\text { impact }\end{array}$} \\
\hline $\begin{array}{l}\text { D1: Working with } \\
\text { others }\end{array}$ & $\begin{array}{l}\text { Public engagement requires an } \\
\text { ability to build trust, understanding, } \\
\text { collaboration and effective } \\
\text { partnerships }\end{array}$ & $\begin{array}{l}\text { Respects and values input } \\
\text { from others } \\
\text { Is sensitive to issues of } \\
\text { diversity and inclusion; } \\
\text { relates well to different } \\
\text { groups; appreciates how } \\
\text { partnerships can enhance } \\
\text { public engagement activity; } \\
\text { responds positively to the } \\
\text { expertise and insights of } \\
\text { other professionals and non- } \\
\text { experts }\end{array}$ & High-Med \\
\hline $\begin{array}{l}\text { D2: } \\
\text { Communication } \\
\text { and dissemination }\end{array}$ & $\begin{array}{l}\text { Effective engagement requires } \\
\text { communication media and methods } \\
\text { appropriate to the purpose and } \\
\text { audience }\end{array}$ & $\begin{array}{l}\text { Can differentiate how they } \\
\text { speak or write for different } \\
\text { audiences; communicate their } \\
\text { personal commitment and } \\
\text { interest in the topic; make } \\
\text { presentations using props and } \\
\text { AV resources; provide } \\
\text { relevant examples, stories, } \\
\text { activities and metaphors; } \\
\text { adapts language to the needs } \\
\text { of particular audiences } \\
\text { - Is sensitive to the needs of } \\
\text { audiences }\end{array}$ & High \\
\hline
\end{tabular}




\begin{tabular}{|c|c|c|c|}
\hline $\begin{array}{l}\text { D3: Engagement } \\
\text { and impact }\end{array}$ & $\begin{array}{l}\text { Engagement projects enable } \\
\text { researchers to develop an } \\
\text { understanding of the social and } \\
\text { ethical implications of their work } \\
\text { and ensure their research has } \\
\text { relevance to and impact on society }\end{array}$ & $\begin{array}{l}\text { - Understands their own } \\
\text { motivation for engagement } \\
\text { - Identifies social, political and } \\
\text { ethical issues of relevance for } \\
\text { particular audiences }\end{array}$ & $\begin{array}{l}X \\
X\end{array}$ \\
\hline
\end{tabular}

Lens descriptors adapted from the NCCPE's Public Engagement Attributes Framework (www.publicengagement.ac.uk/what/skills-and-attributes); Vitae, (C) 2010 Careers Research and Advisory Centre (CRAC) Limited

\section{The undergraduate research conference as a professional development opportunity}

The RDF identifies the characteristics of excellent researchers, shown in the framework as 'descriptors', which are located within four domains and 12 sub-domains, and concern the knowledge, standards, abilities, skills and personal qualities required to be an effective researcher (Vitae, 2014) (Figure 1). For this research, we mapped the results to the public engagement lens, as this most suited the conference process. Table 2 visualises the application of this lens, showing which core researcher skills are aligned against each subdomain within the context of public engagement. The application of the RDF in this paper acknowledges that the majority of BCUR conference attendees are at the earliest career stage of development for most of the descriptors, and therefore concerns itself with whether a core skill has been developed as a result of participation. Where participants made reference to an aspect of their conference experience that aligns with a core skill listed in the public engagement lens, this has been shown as being evidenced (with a tick) or not (with a cross), together with an attempt to indicate the relative strength of the development. Low strength means that there were very few, or zero, references to the use or development of the skill by those interviewed; medium means there were several such references; and high strength points to the fact that there were a significant number of relevant references in the interviews. It should be noted that the scale of strength is relative within the context of the conference experience only, not in relation to other public engagement or learning activities.

Those responsible for the professional development of researchers can use the public engagement lens to 'strategically align training and development towards different areas of expertise' (Vitae, 2014). For example, by considering this study's application of the lens, an 
undergraduate research conference could be designed to focus on specific core skills and improve levels of public engagement.

\section{Discussion}

The results of this study have shown which conference elements are important from the student presenter perspective, and that many of the skills developed through preparation for and participation in undergraduate conferences can be mapped onto Vitae's RDF domains. The ability to evidence core skill development through this mapping exercise demonstrates that the RDF can be used to scaffold undergraduates' learning in terms of graduate attributes and the development of postgraduate level skills.

The balance of oral paper and poster presentations in academic conferences varies between the disciplines. Here, delivering and observing paper presentations provided evidence of: the development of confidence in public speaking; information synthesis; time management; learning to direct work at generic audiences; receiving and giving critical feedback; gaining new knowledge in unfamiliar disciplines; and exposure to good practice. A small number of attendees commented on the value of seeing presenters use very different research approaches; a learning outcome also noted by Garaffa and Brians (2011) in their account of a student's first conference experience. This outcome appeared to take these participants by surprise, demonstrating the rather narrow research context in which many undergraduates operate.

Seymour et al.'s (2004) study of summer research apprenticeships explained the increased confidence of participants that presented their research as being largely due to a reduction of fear of exposing areas of uncertainty in their understanding. While it might be argued that the skills developed from learning to present detailed research work in a concise form are just as applicable within a disciplinary context (Orsmond, Merry and Reiling, 2004), the ability to present complex, technical themes in a jargon-free language accessible to a generic audience is essential for effective dissemination at a national conference (Spronken-Smith et al., 2013).

Mabrouk (2009) found that $11 \%$ of student participants at a discipline academic conference cited oral paper sessions as the most valuable element, while $40 \%$ valued poster sessions the most. In the current study the poster sessions were perceived to advance students' skills and attributes in: writing concisely for an interdisciplinary audience, communicating research 
effectively and confidently giving and receiving critical feedback, employability skills and in recognising and fostering potential collaborations.

At the BCUR conferences, oral paper presenters found the exchange of critical feedback of significant value, helping to conquer self-doubt and extending research ideas and methodologies. This aligns with Crowe, Stanford and Shattell's (2010) findings where 60\% of students surveyed from three NCUR conferences agreed that presentation feedback was challenging and/or helpful. The time set aside for such feedback at BCUR was generally immediately after the presentation. Such 'question and answer' sessions are best supported through the allotment of ample time by conference organisers, as well as effective facilitation by trained session chairs (Hersh et al., 2011). An equal proportion of poster presenters also found critical feedback beneficial to them, hence the importance of specific timed slots when poster authors were required to be situated with their displays.

Networking activities and opportunities, both academic and social, are important and an expected aspect of a conference experience. Critical learning occurs during social, informal exchanges that populate a conference. These 'casual conversations' (Mabrouk, 2009, p 1335) allow students to acquire knowledge about how research processes work within academic social frameworks. Perhaps less expected was the outcome for many attendees that the conference, through engaging students in authentic environments and engendering situated learning (Lave and Wenger, 1991), created an academic community of practice for student researchers. Mabrouk (2009) found that many undergraduates attending technical conferences were motivated to explore potential collaborations, to travel, and to improve their résumés; effectively embracing many of the elements that make up a professional conference experience.

It is important that conferences are dynamic, enriching and beneficial experiences, providing opportunities for the majority, if not all, participants to present their research, rather than simply attending (Helm and Bailey, 2013; Mekolichick and Bellamy, 2012; Wakefield, Ribchester, and France, 2008). There is likely to be a continuum of personal skills development, a confidence continuum, based on the level of active participation in a conference. Undergraduate research conferences arguably provide the flexibility to be customised to allow various stages of research activity to be presented by students, rather than the more customary research cycle in its entirety. 


\section{Conclusion}

A number of institutions use department or university-wide undergraduate student research events to prepare students for national research conferences (Healey and Jenkins, 2009; Seymour et al., 2004). The results here suggest these conference opportunities have significant value for students and enhance their wider professional development, including the public engagement and communication skills that employers value (Archer and Davison, 2008).

Undergraduate research conferences provide rich experiences that offer participants a range of activities, including plenary, panel, workshop, poster and symposia sessions, and networking opportunities. For those interested in the professional development of novice researchers, the alignment of the findings from this study with the RDF provides evidence for the range of impacts on inexperienced practitioners.

Within the broader context of supporting institutional strategies to develop undergraduate research and inquiry (Jenkins and Healey, 2009), HEI's might well view undergraduate research conferences as an economic opportunity to enhance student/graduate research skills and wider graduate attributes (Barrie, 2004; Hill and Walkington, 2016). Such vehicles can also stimulate broader interest in undergraduate research within institutions (BCUR, 2015), aligning and/or supplementing opportunities to engage students in research in a much wider variety of formats than just conferences, such as undergraduate journals, research apprenticeships, and work placements (Walkington, 2015; Walkington and Jenkins, 2008). Across the ninety interviews we see a collective student experience generating benefits that contribute toward an individual's professional development. To ensure these experiences are maximised and that student participants will learn the skills needed in order to meet certain RDF targets (Table 2), conference organisers may wish to:

Ensure equal space, time, attention and importance is afforded to poster sessions and to oral paper presentations

- Allocate adequate time for question and answer sessions following each paper presentation 
- Provide dedicated networking time and activities throughout the programme to enable conversations between students, and for students to understand the skills gained through practice

- Encourage pre-presentation practice, allowing students to understand how a conference looks and feels, and develop their confidence in presenting

- Facilitate attendance by non-presenters so that they also benefit from the overall conference experience and gain sufficient confidence to participate more actively in future events

A conference is just one fleeting event in an academic career. Making participants aware of this type of research dissemination and of the RDF in conference briefings and de-briefings could help participants to better understand and articulate their own academic, professional and employability development (Fraser and Thomas, 2013; Su, 2014).

\section{References}

Anderson, D. and Passera, M. (2015). "Experts and Novices" up-dated: introducing the mini conference. In Festival of Learning conference 2015, 12-16 Jan 2015. Kingston Upon Thames: Kingston University. Accessed 3 March 2016. http://eprints.kingston.ac.uk/id/eprint/32882.

Archer, W. and Davison, J. (2008). Graduate Employability: what do employers think and want? London: The Council for Industry and Higher Education.

Barrie, S.C. (2004). A research-based approach to generic graduate attributes policy. Higher Education Research \& Development, 23, 261-275.

Bazeley, P. and Jackson, K. (2013). Qualitative Data Analysis with NVivo. London: Sage.

British Conference of Undergraduate Research (BCUR) (2015). Developing Undergraduate Research: A Support Pack by the British Conference of Undergraduate Research. University of Central Lancashire: Centre for Research-informed Teaching.

Bray, R. and Boon, S. (2011). Towards a framework for research career development. International Journal for Researcher Development, 2 (2): 99-116. 
Chickering, A. W. and Gamson, Z. F. (1999). Development and Adaptations of the Seven Principles for Good Practice in Undergraduate Education. New Directions for Teaching and Learning, 80: 75-81.

Crowe, M., Stanford, D. and Shattell, M. (2010). Student and Faculty Perceptions of the National Conference on Undergraduate Research (NCUR). Council on Undergraduate Research Quarterly, 31 (1): 14-17.

Ewell, P. and Jones, D. (1996). Indicators of "good practice" in undergraduate education: A handbook for development and implementation. Boulder, CO: National Center for Higher Education Management Systems.

Fraser, K. and Thomas, T. (2013). Challenges of assuring the development of graduate attributes in a Bachelor of Arts. Higher Education Research \& Development, 32, 545 560.

Galetta, A. (2013). Mastering the Semi-structured Interview and Beyond. London: New York University Press.

Garaffa, T. and Brians, C. (2011). Two Views of a Conference Presentation: An Undergraduate's First Research Conference Experience, Journal of Political Science Education, 7 (2): 240-242.

Guterman, L. (2007). What good is undergraduate research, anyway? The Chronicle of Higher Education, 53 (50): 1-6.

Healey, M. and Jenkins, A. (2009) Developing undergraduate research and inquiry. York: HE Academy. Accessed April 2015. https://www.heacademy.ac.uk/node/3146

Helm, H. and Bailey, K. (2013). Perceived Benefits of Presenting Undergraduate Research at a Professional Conference. North American Journal of Psychology, 15 (3): 527-536.

Hersh, C., Hiro, M. and Asarnow, H. (2011). The Undergraduate Literature Conference: A Report from the Field. Pedagogy 11(2): 395-404.

Hill, J. and Walkington, H. (2012). 'One step closer to the real world': engaging students in authentic research dissemination beyond the curriculum. ISSOTL Conference, Hamilton, Ontario, Canada [paper] 27/10/12. 
Hill, J. and Walkington, H. (2016) Developing graduate attributes through participation in undergraduate research conferences. Journal of Geography in Higher Education (in press). DOI: 10.1080/03098265.2016.1140128.

Hounsell, D. (2011). Graduates for the 21st Century: Integrating the Enhancement Themes. Gloucester: The Quality Assurance Agency for Higher Education.

Hunter, A-B., Laursen, S. and Seymour, E. (2007). Becoming a Scientist: The Role of Undergraduate Research in Students' Cognitive, Personal, and Professional Development. Science Education, 91 (1): 36-74.

Jenkins, A. and Healey, M. (2007), 'UK-based undergraduate research programmes', Accessed April 2015. http://www2.warwick.ac.uk/fac/soc/sociology/research/cetl/ugresearch/

Jenkins, A. and Healey, M. (2009). Developing undergraduate research and inquiry. York: The Higher Education Academy.

Kinkead, J. (2003). Learning Through Inquiry: An Overview of Undergraduate Research. New Directions for Teaching and Learning, 2003 (93): 5-18.

Lave, J. and Wenger, E. (1991). Situated Learning: legitimate peripheral participation. Cambridge: Cambridge University Press.

Lopatto, D. (2009) Science in Solution: The Impact of Undergraduate Research on Student Learning. Tucson, AZ: Research Corporation for Science Advancement .

Mabrouk, P. (2009). Survey Study Investigating the Significance of Conference Participation to Undergraduate Research Students. Journal of Chemical Education, 86 (11): 13351340.

Mekolichick, J. and Bellamy, J. (2012). Research Experiences for Undergraduates: Student Presenters' Perceptions of Mentoring and Conference Presentation by Generational Status and Sex. Perspectives on Undergraduate Research and Mentoring (PURM), 1 (2): 1-14.

Miles, M.B., Huberman, A.M. \& Saldana, J. (2015). Qualitative Data Analysis: A Methods Sourcebook, $3^{\text {rd }}$ ed. London: Sage Publications. 
Orsmond, P., Merry, S. and Reiling, K. (2004). Undergraduate project work: Can directed tutor support enhance skills development? Assessment \& Evaluation in Higher Education, 29 (5): 625-642.

Osborn, J. and Karukstis, K. (2009). The benefits of undergraduate research, scholarship, and creative activity. In: M. Boyd and J. Wesemann (Eds.), Broadening Participation in Undergraduate Research: Fostering Excellence and Enhancing the Impact. Washington, DC: Council on Undergraduate Research, 41-53.

Seymour, E., Hunter, A.-B., Laursen, S. L. and DeAntoni, T. (2004). Establishing the benefits of research experiences for undergraduates in the sciences: First findings from a three-year study. Science Education, 88: 493-534.

Spronken-Smith, R., Brodeur, J., Kajaks, T., Luck, M., Myatt, P., Verburgh, A., Walkington, H. and Wuetherick, B. (2013). Completing the Research Cycle: A Framework for Promoting Dissemination of Undergraduate Research and Inquiry. Teaching and Learning Inquiry: The ISSOTL Journal, 1 (2): 105-118.

Strauss, A. and Corbin, J. (1998). Basics of Qualitative Research - Techniques and Procedures for Developing Grounded Theory, $2^{\text {nd }}$ ed. London: Sage Publications.

Su, Y. (2014). Self-directed, genuine graduate attributes: the person-based approach. Higher Education Research \& Development, 33, 1208-1220.

Swift, J., Ambos, E., Swift, C. and Ash, C. (2012). A Regional Undergraduate Research Conference Comes of Age in Southern California. Council on Undergraduate Research Quarterly, 32 (4): 21-27.

Taylor, S. and Bogdan, R. (1984). Introduction to Qualitative Research Methods: The Search for Meanings. New York: Wiley.

UKCES (2014a), Working Futures 2012-2022. Accessed April 2015. https://www.gov.uk/government/uploads/system/uploads/attachment_data/file/298510/ working-futures-2012-2022-main-report.pdf;

UKCES (2014b) Forging Futures, building higher level skills through university and employer collaboration. Accessed April 2015. http://www.universitiesuk.ac.uk/highereducation/Documents/2014/ForgingFutures.pdf 
Vitae (2014) About the Vitae Researcher Development Framework. [Online]. Accessed April 2015. https://www.vitae.ac.uk/researchers-professional-development/about-the-vitaeresearcher-development-framework.

Wakefield, K., Ribchester, C. and France, D. (2008) The Chester Graduate/Undergraduate Employability Conference and Employability Strategy, Planet, 21: 33-36.

Walkington, H. (2008). Geoverse: piloting a national e-journal of undergraduate research in geography. Planet, 20: 41-46.

Walkington, H. and Jenkins, A. (2008). Embedding Undergraduate Research Publication in the Student Learning Experience. Brookes E-journal of Learning and Teaching, 2 (3). Accessed April 2015.

http://bejlt.brookes.ac.uk/article/embedding_undergraduate_research_publication_in_th e_student_learning_experi/.

Walkington, H. (2014). Quality enhancement of undergraduate research - further strategies to increase student engagement in research dissemination. Brookes E-journal of Learning and Teaching, 6 (1). Accessed April 2015. http://bejlt.brookes.ac.uk/paper/qualityenhancement-of-undergraduate-research-further-strategies-to-increase-studentengagement-in-research-dissemination/

Walkington, H. 2015. Students as researchers: Supporting undergraduate research in the disciplines in Higher Education. York: Higher Education Academy. Accessed August 2015 https://www.heacademy.ac.uk/sites/default/files/resources/Students\%20as\%20research $\underline{\text { ers_1.pdf }}$

Wenger, E. (1998). Communities of Practice; learning, meaning and identity. Cambridge: Cambridge University Press.

Xiangdong, L. (2015). Mock conference as a situated learning activity in interpreter training: a case study of its design and effect as perceived by trainee interpreters. The Interpreter and Translator Trainer, 9 (3). 